\title{
FAIR JURY SELECTION PROCEDURES
}

IN the recent case of Swain $v$. Alabama ${ }^{1}$ the Supreme Court served notice that it is not ready to wage a final campaign against exclusion of Negroes from juries. ${ }^{2}$ Robert Swain, a Negro, was convicted of rape in Talladega County, Alabama, and sentenced to death. Unchallenged evidence showed that no Negro had ever served on a Talladega petit jury. The Supreme Court upheld Swain's conviction.

Swain alleged that the exclusion of Negroes from petit juries resulted from the county prosecutor's misuse of the peremptory challenge." Alabama uses a variant of the peremptory challenge known as the struck jury. After the members of the petit jury venire are selected, the defense strikes two and the prosecutor one in alternate turns until only twelve members are left. In a capital case the venire may consist of more than 75 people, thus giving both attorneys a large number of strikes. In Swain's trial, the prosecutor struck all six Negroes from the venire. But both the majority and the dissenters agreed that a finding of discrimination could not be based solely on the prosecutor's action in a

1. 380 U.S. 202 (1965).

2. The United States Commission on Civil Rights has reported that

[T] he problem of racial exclusion from jury service is relatively widespread and, in certain areas, deeply entrenched. The serious and continuing nature of the problem is revealed by the frequency of cases in which the issue of jury cxclusion is ralsed and by local situations which the facts of those cases disclosed; by the plain statements of judges and official observers; and by various field studies conducted by the Commission's staff.

1961 U.S. Commission on Civil Rights REPORT (Book 5) at 90.

Exclusion persists despite the fact that discrimination in the selection of jurors has been prohibited by statute, 18 Stat. 336-37 (1875), 18 U.S.C. $\$ 243$ (1964), and by a long series of judicial decisions. A complete list of Supreme Court cases on discriminatory selection of jurors appears in Swain, supra at 228-29.

3. Id. at 209-10, 222-23. The peremptory challenge is used in every American jurisdiction. It is regarded as an aid to finding an impartial jury because it permits counsel to remove anyone he suspects is biased without assigning a specific cause for his suspicion. In most jurisdictions, the number of challenges allowed varies with the offense. Some jurisdictions allow the prosecution and the defense the same number of challenges, whlle many others give more challenges to the defense. See generally A.L.I. Code of CriminaL Procedure, 855-62 (1930). A list of current state statutes on peremptorics appears at 880 U.S. at 217 n.20.

4. Id. at 210. See also ALA. CODE tit. 30, \$\$ 60-64 (1958). The more typical challenge system works as follows: the prosecution and defense are each allowed a specific number of challenges. Veniremen are brought in one at a time and after voir dire cxamination either counsel may challenge peremptorily. The first twelve veniremen to go un. challenged constitute the petit jury.

5. 380 U.S. at 210. 
single case. ${ }^{6}$ The real controversy in Swain concerned the prosecutor's use of the peremptory challenge to exclude all Negroes from juries over a long period.

Speaking for the majority, Mr. Justice White held that the record in Swain did not "with any acceptable degree of clarity, show when, how often, and under what circumstances the prosecutor alone has been responsible for striking . . Negroes . . . . The record did, in fact, indicate that defense attorneys often struck Negroes. The majority concluded, therefore, that the record was insufficient to raise the issue of whether consistent challenging of all Negroes by prosecutors violated the Fourteenth Amendment. ${ }^{8}$ On the other hand, Mr. Justice White did suggest that

when the prosecutor in a county, in case after case, whatever the circumstances, whatever the crime and whoever the defendant or the victim may be, is responsible for the removal of Negroes . . . with the result that no Negroes ever serve on petit juries, the Fourteenth Amendment claim takes on added significance. ... In these circumstances, giving even the widest leeway to the operation of irrational but trial-related suspicions and antagonisms, it would appear that the purposes of the peremptory challenge are being perverted. ... ${ }^{9}$

But the high standards of proof required by Mr. Justice White may vitiate the practical significance of this dictum. Defense attorneys would find it extremely difficult to "show when, how often, and under what circumstances the prosecutor alone has been responsible for striking ... Negroes," especially since the states are under no obligation to keep a complete list of challenges of Negro panel members.

The three dissenters, in an opinion written by Mr. Justice Goldberg, stated that they believed the record in Swain had demonstrated the prosecutor's discriminatory intent. ${ }^{10}$ They argued, however, that even if the record did not expressly show this intent, it was

undisputed that no Negro has ever served on any petit jury in the history of Talladega County. Under Norris, Patton and the other

6. Id. at 222, 245. This is in accord with numerous decisions in lower federal and state courts. See, e.g., Hall v. United States, 168 F.2d 161, 164 (D.C. Cir.), cert. denied, 334 U.S. 853 (1948); People v. Roxborough, 307 Mich. 575, 12 N.W.2d 466 (1943), cert. denied, 323 U.S. 749 (1944). See also Note, 61 HARv. L. REv. 1455 (1948).

7. 380 US. at 224.

8. Id. at $224-25$.

9. Id. at 223-24.

10. Id. at 233-35. The dissenters relied primarily on the prosecutor's own testimony that he often approached defense counsel before the formal striking process began and asked them whether they wished to remove all Negroes. 
cases discussed above, it is clear that petitioner by proving this made out a prima facie case of unlawful jury exclusion. The burden of proof then shifted to the State to prove, if it could, that this exclusion was brought about for some reason other than racial discrimination in which the State participated. ${ }^{11}$

In Norris, ${ }^{12}$ Patton $^{13}$ and the other cases ${ }^{14}$ referred to by Mr. Justice Goldberg, the Supreme Court had held that a prima facie case of discrimination was established when the record indicated that no Negroes had served on jury venires over a long period. Mr. Justice Goldberg felt that the same factors-"availability of evidence, simplicity, and workability" - which led the Court to shift the burden of proof to the state in these cases should have led the Court to shift the burden in Swain..$^{15} \mathrm{Mr}$. Justice White disagreed and felt that Justice Goldberg was "woodenly" and "blind[ly]" applying to petit jury cases the "rule of exclusion" established in jury venire cases. ${ }^{10}$

Given the Supreme Court's record in civil rights, its refusal to reverse a conviction upon a showing that no Negro has ever served on a petit jury is anomalous. One possible explanation is that the Court believed that no rule about peremptory challenges could ensure substantial representation of Negroes on juries, and that therefore it was senseless to begin to fashion any rule. Certainly, Mr. Justice Goldberg's "rule of exclusion" would not work, since it could not be applied when more than a token number of Negroes had served and could not be used to judge the prosecutor's actions in a single case. A prosecutor could evade the rule altogether by allowing a few Negroes to appear in misdemeanor cases or in some cases involving white defendants. Of course, a court could meet these tactics by applying the rule of exclusion to categories of cases involving Negro defendants ${ }^{17}$-misdemeanor, felony, capital. Each of these categories could in turn be subdivided according to whether the victim was white or Negro. If in any category no Negro had ever served on a petit jury a prima facie case of dis-

11. Id. at 238.

12. Norris v. Alabama, 294 U.S. 587 (1935).

13. Patton v. Mississippi, 332 U.S. 463 (1947).

14. The other cases discussed by Mr. Justice Goldberg include Arnold v. North Caro. lina, 376 U.S. 773 (1964); Harper v. State, - Miss. —, 171 So. 2d 129 (1965).

15. 380 U.S. at $240-41$.

16. Id. at 227. Admittedly petit jury cases are more complex than venire cascs (be. cause of such factors as the peremptory challenge). But this greater complexity does not justify upholding a conviction in a county where no Negro has ever served on a petit jury. Mr. Justice Goldberg was correct to insist that the "rule of exclusion" be applied in Swain.

17. The court would not apply the rule to cases involving white defendants because in such cases it can be assumed that the defense is challenging most of the Negrocs. 
crimination would be established. But even this category-by-category approach would not ensure fair representation of Negroes. The number of cases in a category would frequently be so small that it might take years before a pattern of discrimination could emerge. And within each category the prosecutor could allow a few Negroes to appear when the outcome was certain while challenging them in other cases.

Admittedly, a more rigorous supervision of the prosecutor could be achieved if his actions in a single case were subject to review. But both the majority and dissent in Swain agreed that a court could not infer discrimination from the prosecutor's challenges in any one case. ${ }^{18}$ Since the prosecutor might legitimately feel that all the Negroes on a particular panel were biased, the Court's position seems correct.

The difficulties in supervising the prosecutor's use of the peremptory challenge may explain the Court's excessive caution in Swain. But if the Court realized these difficulties, it should have searched for an alternative method to ensure more adequate Negro participation on petit juries. One method would be to require that Negroes be more fairly represented on the venire. In many Southern counties fair representation on the venire would make it impossible for prosecutors to strike all Negroes. For example, in Alabama, where the prosecutor has half as many strikes as the defense counsel, Negroes cannot be excluded if they represent more than one-third of the venire and if the defense counsel strikes only whites. ${ }^{18}$

In Swain, the Court had an opportunity to begin effective supervision of venires, but refused to grasp it.. ${ }^{20}$ The record indicated that Negroes constituted $26 \%$ of the age-group eligible for jury service in Talladega

18. See note 6 supra.

19. Since the Alabama system gives the prosecution one-third of the strikes, he is theoretically able to temove one-third of the veniremen, white or Negro. Actually, the percentage of venirement he can remove decreases as the size of the venire decreases. With a venire of 75 , the prosecutor can strike 21 people [1/3 (75-12)], or $28 \%$. With a venire of 50 , he can strike 13 people, or $26 \%$. And with a venire of 24 , he can strike only 4 people, or $17 \%$.

Under the more typical challenge system, see note 4 supra, the percentage of Negroes that a prosecutor is able to remove from the venire depends on the number of challenges allowed him and the defense attorney. In Virginia, for example, prosecutors are allowed only four challenges in felony cases, while in South Carolina they are allowed only five. VA. CODE ANN. § 19.1-208 (1950); S.C. CODE § 38-211 (1962). Thus their ability to remove all Negroes would be ended in many cases if Negroes were fairly represented on venires.

It should be rememberd, moreover, that the prosecutor may not want to use all his strikes or challenges against Negroes. In many cases he may suspect white veniremen of being biased and feel compelled to remove them from the venire.

20. Mr. Justice White expressly refused to examine the relationship between Negro representation on venires and the prosecutor's use of the peremptory challenge. 380 U.S. at $228 \mathrm{n} .32$. 
County and only 10 to $15 \%$ of the veniremen. ${ }^{21}$ Negroes were thus under-represented by about $50 \% .{ }^{22} \mathrm{Mr}$. Justice White stated, however, "[W]e cannot say that purposeful discrimination based on race alone is satisfactorily proved by showing that an identifiable group in a community is under-represented" to this extent..$^{23}$ White's "purposeful discriminaton" test ladens the Negro defendant with almost impossible burdens. First, if the defendant shows under-representation, he must prove further that it was not caused by the fact that Negroes were less qualified than whites to serve as jurors. Many standards of jury qualification are so vague that the Negro defendant would not be able to offer the necessary proof. For example, in Alabama, jurors must be "male citizens in the community over 21 who are reputed to be honest, intelligent men and [who] are esteemed for their integrity, good character and sound judgment." ${ }^{24}$ In Swain, White claimed that the defendant made no "meaningful attempt to demonstrate that the same proportion of Negroes [as whites] qualified under the standards being administered by the commissioners." 25 It would seem far more reasonable to burden the jury commissioners with explaining the administration of their standards. Second, White would have the defendant prove that the under-representation was caused by "purposeful discrimination" rather than by "haphazard" or "imperfect" selection methods.20 The defendant could meet this burden only by demonstrating the commissioners' subjective intent to discriminate.

Despite these criticisms, it must be conceded that the majority's assignment of the burden of proof was consistent with earlier jury venire decisions. In the past the Court had found a prima facie case of purposeful discrimination only when there was complete exclusion of Negroes or blatant tokenism. ${ }^{27}$ The Court had made no effort to

21. 380 U.S. at 205.

22. Mr. Justice White, however, stated that Negroes were under-represented by $10 \%$. Id. at 208-09. This is plain error. Presumably he meant that Negroes were under-reprcsented by about 10 percentage points $-26 \%-15 \%$.

23. Ibid.

24. This is Mr. Justice White's description of Alabama law. Id. at 206. Sec Ars. Cone tit. 30, $\S \S 20,21$ (1958). Alabama law also states that illiterates cannot serve as jurors unless they are freeholders or householders. Whether this is a "rational classification" was not raised in Swain.

25. 380 U.S. at 209.

26. Ibid.

27. Typical cases in which the Court did find discrimination are Norris v. Alabama, 294 U.S. 587 (1935) (no Negro called for jury service within memory); Pierre v. Louislana, 306 U.S. 354 (1939) (one Negro called for jury service within memory); Patton v. Mississippi, 332 U.S. 463 (1947) (two or three Negroes called in thirty years).

The Court did not find discrimination in Brown v. Allen, 344 U.S. 448, 477 (1959), 
establish more rigorous statistical tests for showing purposeful discrimination. Nor had the Court attempted to impose upon the jury commissioners any affirmative obligation to secure fair representation for Negroes. ${ }^{28}$

It is unlikely that the Court's unwillingness to impose affirmative obligations on jury commissioners has been due primarily to its reluctance to interfere with state activities. First, the Court has not supervised even federal jury commissioners. ${ }^{29}$ And second, the Court has not hesitated to place affirmative duties on state officials in equal protection cases involving desegregation and reapportionment. ${ }^{30}$ The more serious problem facing the Court has been its inability to establish a selection procedure which reasonably can be required of the states. Ideally, jury commissioners should choose prospective jurors at random from a comprehensive list and then check each juror's qualifications. ${ }^{31}$

where Negroes constituted $38 \%$ of the eligible veniremen and only $7 \%$ of the actual veniremen.

28. There was one minor exception. The Court held that jury commissioners who select prospective jurors from their personal acquaintances have a duty to become acquainted with Negroes in the community in order to ascertain whether there are Negroes qualified for jury service. Hill v. Texas, 316 U.S. 400, 404 (1942). See also Smith v. Texas, 311 U.S. 128 (1940). As indicated in note 27 supra and accompanying text, however, the commissioners did not have to fear judicial supervision once they placed more than a token number of qualified Negroes on the jury lists.

29. The Court has not imposed more stringent requirements on federal commissioners than on state commissioners. A recent survey by the Southem Regional Council demonstrated that Negroes were decidedly under-represented on federal venires in many sections of the South. See N.Y. Times, April 25, 1965, p. 76, col. 3. And in a letter to the Speaker of the House of Representatives, February 11, 1965, Attomey General Katzenbach stated that ". . . there appears to be a serious need for the strengthening of jury selection methods in the Federal Courts." H.R. REP. No. 261, 89th Cong., Ist Sess. 3 (1965).

Two federal jury selection cases are presently pending before the Fifth Circuit. Jackson v. United States, appeal docketed, No. 21,345 (1965) and Rabinowitz v. United States, appeal docketed, No. 21,256 (1965).

30. Allowing Negro children to enter previously all-white schools has created administrative problems for the state in terms of classroom facilities, transportation facilities, teacher shifts, etc. The Court has taken this into account only to the extent of permitting states to desegregate "with all deliberate speed." Brown v. Board of Education, 349 U.S. 294, 299-301 (1955).

Reapportionment has also involved administrative difficulties. Mfore significantly, the reapportionment cases marked an entirely new form of judicial intervention in the affairs of the states. See Justice Frankfurter's dissenting opinion in Baker v. Carr, 369 U.S. 186, 266 (1962).

31. Random selection ensures that commissioners do not choose jurors on account of their race. "Jurymen should be selected as individuals, on the basis of individual qualifications, and not as members of a race." Cassell v. Texas, 339 U.S. 282, 286 (1950). See Collins v. Walker, $329 \mathrm{~F} .2 \mathrm{~d} 100$ (5th Cir.), second petition for rehearing denied, $335 \mathrm{~F} .2 \mathrm{~d}$ 417 (5th Cir.), cert. denied, 379 U.S. 901 (1964), where the Fifth Circuit reversed a con. 
Unfortunately, however, no comprehensive list of names exists in many parts of the South. Because of past discrimination current voter registration lists grossly under-represent Negroes. Telephone directories, utility customer records, and local tax lists are also likely to under-represent Negroes substantially. ${ }^{32}$ This lack of representative sources probably explains the Court's past unwillingness to formulate a more rigorous statistical standard than the rule of exclusion. It also explains the Court's tolerance of such haphazard and imperfect selection procedures as the "key man" system, whereby the power of selection is placed in the hands of a few community leaders. ${ }^{33}$ Of course, the Court might have required the jury commissioners to use the most representative source available. But since, in the past, almost all sources were unrepresentative, their use might have been even more unsatisfactory than haphazard selection methods. Those few representative lists which did exist, for example, city directories, ${ }^{34}$ covered only certain parts of counties.

In the future, however, the Voting Rights Act of $1965^{85}$ will ensure the existence of representative registration lists. But there is no guarantee that jury commissioners will use these lists as sources without judicial prodding. The Court, therefore, should require that jury commissioners use voting lists unless another more comprehensive list is

viction because Negroes had been intentionally included on a grand jury. Sec also Comment, 74 YALE L.J. 887 (1965).

32. As of December 31, 1963, only $50 \%$ of the households in Mississippi had telephones. Percentages for the other Southern states ranged from 59\% (Arkansas) to $72 \%$ (Louisiana). By contrast, $94 \%$ of Connecticut households had telcphoncs. STATISTICAL ABSTRACT OF THE UNITED STATES 517 (1965). It can be presumed that a disproportlonate number of the Southern households without telephones are Negro. Utility customer records will also under-represent Negroes because utility bills are often paid by the landlord or plantation manager rather than by tenants.

This lack of representative sources has led some civil rights lawyers to demand that jury commissioners be required to use modern sampling and polling techniques such as those developed by George Gallup. See Brief for Appellants, pp. 15.20, Blllingsley v. Clayton, appeal docketed, No. 22,304, 5th Cir., June, 1965.

33. Under the "key man" system, a few community leaders are asked to recommend prospective jurors. Since the key men are usually white, this system is likely to result in under-representation of Negroes. It is also likely to result in the sclection of "reliable" Negroes who will be sensitive to the wishes of the white leadership community. The jury commissioners in Talladega County relied partly on the key man system. 880 U.S. at 207 n.4.

34. A city directory is a book containing the names and addresses of local residents and extensive advertising by local businessmen. It is put out by the local businessmen, and often covers more households than the telephone directory. It would not, however, cover households in rural areas of a county.

35. P.L. 89-110, 79 Stat. 437 (1965). 
reasonably available. ${ }^{36}$ The use of voting lists could be required under the established doctrine that states must refrain from "purposeful discrimination." It is clear that selection methods which appear haphazard can easily mask purposeful discrimination. Jury commissioners may intentionally choose selection methods which under-represent Negroes and then testify that the under-representation was purely fortuitous. This testimony would be impossible to impeach. ${ }^{37}$ The Court can legitimately require states to use a single source list, instead of the usual potpourri, ${ }^{38}$ in order to minimize the possibility of "fortuitous" discrimination..$^{39}$ The constitutional basis for Court action is, therefore, clear.

Recently, however, there have been suggestions for congressional legislation on juries, ${ }^{40}$ and it might be argued that the Court should forbear and let Congress deal with the problem. The advisability of such forbearance depends, in part, on whether there are substantial advantages in congressional, as opposed to judicial, action. Any rule announced by the Court would almost certainly apply to previous convictions. ${ }^{41}$ To those who fear retroactive application, one apparent ad-

36. If the entire county consists of one city, the city directory may be a more representative source than the registration lists. It is also possible that a state might not wish to restrict jury service to registered voters. Such a state should be allowed to place the names of non-voters on a consolidated source list, but only upon the condition that the new source list is no less representative than the registration list itself. This condition prevents the state from adding only white non-voters to the consolidated source list.

The requirement of a single source list will probably force most jurisdictions to change their entire jury list. This may mean that the state will have to delay all its criminal proceedings for several weeks. The attorney general of Maryland recently instituted such a delay when the state's venires were declared unconstitutional by the MIaryland Court of Appeals because prospective jurors had to affirm their belief in God. Sce Schowgurow v. State, 34 U.S.L. WEEK 2198 (Md. Ct. App. Oct. 11, 1965); Baltimore Sun, Oct. 14, 1965. p. C26, col. 1; N.Y. Times, Oct. 30, 1965, p. 54, col. 1.

37. The testimony of the commissioners could be negated only if there were com. plete exclusion or blatant tokenism. See note 27 supra and accompanying text.

38. In Talladega County, for example, the commissioners apparenty used "city directories, [voter] registration lists, club and church lists, conversations with other persons in the community, both white and colored, and personal and business acquaintances." 380 U.S. at 207. When there are so many sources, it becomes difficult for the courts to supervise the commissioners effectively.

39. The likelihood of disguised discrimination undoubtedly influenced the Court's opinions in Hill v. Texas, 316 U.S. 400 (1912), and Smith v. Texas, 311 U.S. 128 (1940), where the commissioners testified that they did not purposely discriminatc, but that they didn't personally know any qualified Negroes.

40. President Johnson has announced that he will ask the next session of Congress for legislation aimed at preventing "injustice to Negroes at the hands of all-rwhite juries." N.Y. Times, Nov. 17, 1965, p. 1, col. 4.

41. The constitutional principles enunciated by the Court in Grifin v. Illinois, 351 
vantage of legislation would be that Congress could apply its statute prospectively only. It is not clear, however, that retroactive application could, in fact, be avoided by legislation, even if Congress declared that the legislation applied prospectively only. Congress derives its power to legislate about state juries from Section 5 of the Fourteenth Amendment. ${ }^{42}$ The constitutional theory would be that the legislation was necessary to enforce Negro defendants' rights to the equal protection of the laws. A decision upholding the legislation as applied to a particular state might be based, at least implicitly, on a finding that the state had been violating the Fourteenth Amendment. After such a decision, a Negro defendant, convicted before the passage of the Act, could argue that his conviction should be reversed because the decision established that his state had infringed his constitutional rights. The Court might find it difficult to reject this argument and avoid retroactive application of his constitutional rights..$^{43}$

A second possible advantage of action by Congress is that it could impose a more rigorous requirement than the one suggested in this Note. Congress could demand, for example, that every state employ source lists which do not under-represent Negroes by more than $10 \%$. Or Congress could direct federal officials to take a census in order to draw up new source lists. These suggestions would ensure more prompt compliance and would relieve the states of some of the financial burden of implementing the new requirement. The Court, of course, could not send in federal officials. Nor is the Court likely to promulgate a precise mathematical rule for Negro representation on source lists. And probably the Court would not require completely new source lists

U.S. 12 (1956) (free trial transcript for indigent appellant), Gideon v. Wainwright, 372 U.S. 335 (1963) (right to counsel), and Jackson v. Denno, 378 U.S. 868 (1964) (cocrced confession), were applied retroactively by the Court in Eskridge v. Washington, 857 U.S. 214 (1958), Doughty v. Maxwell, 376 U.S. 202 (1964), and MeNerlin v. Denno, 978 U.S. 575 (1964). The reason for applying these principles retroactively was that they "went to the fairness of the trial-the very integrity of the fact-finding process." Linkletter $v$. Walker, 381 U.S. 618, 639 (1965). A Court decision on jury selection procedurcs would also go to the "integrity of the fact-finding process."

42. "Section 5. The Congress shall have power to enforce, by appropriate legislation, the provisions of this article."

43. However, the legislation might be upheld on other theories which would not require retroactive application. For example, the Court could find that Congress meant to ensure equal protection in the future and that Congress did not make specific findings about denials of equal protection in the past. Or, the Court could uphold the legislation on the theory that Congress found a denial of equal protection in jury sclection throughout the South, but that Congress did not find discrimination in any partic. ular county. Therefore, a defendant from any particular county could not use the legis. lation as proof of past discrimination. 
unless it determines that a less burdensome requirement, such as the "most representative source" rule, is insufficient.44

But the fact that Congress could impose stricter standards on the state does not justify judicial forbearance. Action by the Court would in no way impair Congress' ability to act more vigorously later. Thus the Court should not hesitate to establish the "most representative source" requirement. Having held that purposeful discrimination is forbidden, the Court should not allow states to use selection methods which frequently mask such discrimination.

If the new source requirement is established, problems of administration would remain. When a defendant ${ }^{45}$ shows that Negroes are under-represented on venires and that the state is not using the proper source, the court would reverse his conviction. But if the state is using the proper source and Negroes are still under-represented on venires, the administration of the rule would become more complex. First the defendant must demonstrate that the percentage of Negroes on venires is less than the percentage of Negroes on the source list. Upon this demonstration, the burden should shift to the state to show a nondiscriminatory reason for the disparity. Generally, a state would try to show that the disparity is caused by the local Negroes' relative lack of qualifications. ${ }^{46}$ Of course, the state would have to show that its standards of qualification are constitutionally permissible, ${ }^{4 i}$ and that they are fairly applied.

\footnotetext{
44. Another advantage which might be ascribed to congressional legislation is that it expresses a national consensus and will therefore elicit greater compliance than a judicial decision. This proposition may have been valid in 1954 when it appeared to some Americans that "nine old men" were trying to foist civil rights on an unconcerned nation. But since the passage of the Civil Rights Act of 1964 and the Voting Rights Act of 1965 the national consensus on civil rights is abundanty clear, and compliance is unlikely to be greater because Congress, rather than the Court, has acted.

45. In the past, challenges to selection methods have invariably come from Negro defendants. Recently, however, Negro citizens have brought class action suits against state jury officials, and the Department of Justice has announced it will intervene in some of these suits. N.Y. Times, Oct. 26, 1965, p. 28, col. 3. On the statutory basis for such suits, see Cassell v. Texas, 339 U.S. 282, 303-04 (1950) (Jackson, J., dissenting).

White defendants have traditionally been barred from raising the issue of discrimination against Negroes on the ground that they lacked standing. Comment, 74 YALE L.J. 919, 920 \& n.10 (1965). This "same class" rule was recently rejected in Allen v. State, 110 Ga. App. 56, 137 S.E.2d 711 (1964), and has been cogently criticized in Comment, supra.

46. Occasionally, the state might make another showing-e.g., that a disproportionate number of Negroes neglect to answer summons to report for jury service or that a disproportionate number of Negroes are no longer at the address listed on the source list.

47. The constitutionality of a qualification is presently judged by reference to the "cross section" test. In Thiel v. Southern Pacific Co., 328 U.S. 217, 220 (I910), the Court held that federal juries must be drawn from "a cross section of the community" and must not systematically and intentionally exclude economic, geographic, political, racial,
} 
If the Court treats selection methods and qualifications in the above manner, it can ensure that in many Southern counties there will be enough Negroes on the venire so that the prosecutor cannot challenge them all without help from the defendant. The Court's supervision will obviously be most effective in those counties where there is a large Negro population, and these are the counties which are most likely to discriminate in the selection of jurors. ${ }^{48}$ The Court's supervision will also be very effective in states which allow the prosecutor only a few challenges and in states which give the prosecutor only half as many challenges as the defendant.40

A serious problem would be raised, however, if a state changes its peremptory challenge system in order to evade the supervisory procedure outlined in this Note. For example, a state could give the prosecutor three times as many challenges as the defense, and thus allow the prosecutory to remove all Negroes even if they constituted $75 \%$ of the venire. ${ }^{50}$ But any legislation which gave the prosecutor more challenges than the defendant would appear to violate the Fourteenth Amendment guarantee of due process. The peremptory challenge has never been regarded as an instrument to allow the prosecutor an advantage in the selection of juries. ${ }^{51}$ No state gives the prosecutor more

religious or social groups. In Brown v. Allen, 344 U.S. 449,474 (1953), the Court sald that the states must use a source which "reasonably reflects a cross-section of the population suitable in character and intelligence for [jury] duty." Thus a state qualification can be judged by seeing if it systematically and intentionally excludes any of the groups covered by the cross section test.

48. The following important jury cases have taken place in counties where Negrocs constituted at least $33 \%$ of the population: Pierre v. Louisiana, 306 U.S. 355 (1989); Patton v. Mississippi, 332 U.S. 463 (1947); Brown v. Allen, 344 U.S. 443 (1958); Harper v. State, - Miss. - 171 So. 2d 129 (1965). Two of the four Supreme Court cases on grand jury discrimination have taken place in counties where Negroes constituted at least $33 \%$ of the population: Eubanks v. Louisiana, 356 U.S. 584 (1958); Arnold v. North Carolina, 376 U.S. 773 (1964).

In general, the sections of the South with the highest Negro population discriminate most against Negroes. See KeY, Southern Politics in StaTe ANd Nation 5.6, 581, 510.41 (1950).

49. Virginia and South Carolina allow the prosecutor only four and five challenges respectively. See note 19 supra. Alabama, Georgia, Maryland, North Carolina and South Carolina all give the defendant at least twice as many strikes or challenges in felony and capital cases. AlA. Code tit. 30, §64 (1958); GA. Code ANN. §59.805 (1937); MD. ANN. Code, Rules Proc. 746 (1957); N.C. GEN. STAT. \$§ 15-163-164 (1953); S.C. CODE ANN. \& 88211 (1962).

50. This is assuming that the number of challenges allowed is substantial-e.g., 21 for the prosecution and 7 for the defense, not 3 and 1 respectively.

51. Initially the peremptory challenge was regarded as an instrument of the defense. Thus, Blackstone wrote that ". . . in criminal cases, or at least in capital oncs, there is, in favorem vitae, allowed to the prisoner an arbitrary and capricious species of challenge 
challenges than the defendant, and many give the prosecutor less. ${ }^{62}$ To reverse the advantage would pervert the purposes of the peremptory challenge.

The state, however, may amend its challenge system in a way which does not on its face violate due process. For example, Virginia and Texas now give the prosecutor and defendant the same number of challenges, while Alabama and Georgia give the defendant twice as many. ${ }^{53}$ If Alabama or Georgia changed to the system of Virginia and Texas, the prosecutor could remove many more Negroes, but the new system would not appear to violate due process. Of course, a state might be reluctant to change its policy of favoring defendants solely because of the race issue. ${ }^{54} \mathrm{Or}$, the state legislature might fear that such a change would make it difficult for white defendants in civil rights cases to obtain an all-white jury. ${ }^{55}$ Finally, the state legislature might fear that its action would spur the Court to abolish the peremptory challenge for prosecutors altogether. This latter possibility was suggested by Mr. Justice Goldberg in Swain.56

If the legislature changed the challenge system, the Court might respond in another way. In Gomillion v. Lightfoot, ${ }^{57}$ Negro citizens of Alabama challenged a state redistricting measure which was valid on its face but which was allegedly passed to deprive petitioners of their right to vote in the city of Tuskegee. The Court held that if petitioners' allegations were proved, they would demonstrate that "the legislation is solely concerned with segregating white and colored

to a certain number of jurors, without showing any cause at all, which is called a peremptory challenge; a provision full of that tenderness and humanity to prisoners for which our English laws are justly famous." 4 BLAckstone, Commentaries 353 (I3th cd. 1796). See also Mr. Justice Goldberg's opinion, 380 U.S. 202, 242-44.

52. The Southern states which give the defense more challenges are listed in note 49 supra. FED. R. CRMr. P. 24(b) allows each side 20 challenges in apital cases, but gives the government 6 and the defense 10 in non-capital felony cases.

53. Tex. Code Crns. Proc. tit. 8, arts. 615, 634 (1941); VA. Code ANs. \$ 19.1-203 (1960). The Alabama and Georgia statutes are listed in note 49 supra.

54. Alabama, for example, has allowed defendants more challenges since at least 1867 . See 380 U.S. 202,211 n.8.

55. The existence of an all-white jury has been significant in the acquittal of white defendants such as Collie Leroy TVilkins and Thomas L. Coleman. See N.Y. Times, Oct. 21, 1965, p. 1, col. 6; id. Oct. 23, 1965, p. 1, col. 4.

56. 380 U.S. at 243-44. Mr. Justice Goldberg pointed out that the peremptory challenge is not constitutionally required, while "trial by an impartial jury" is. "Were it necessary," he continued, "to make an absolute choice between the right of a defendant to have a jury chosen in conformity with the requirements of the Fourteenth Amendment and the right to challenge peremptorily, the Constitution compels a choice of the former."

57. 364 U.S. 339 (1960). 
voters by fencing Negro citizens out of town so as to deprive them of their pre-existing municipal vote." ${ }^{\circ}$ Similarly, in the challenge situation, a Negro might be able to demonstrate that the state legislature was "solely concerned" with depriving Negroes of the right to serve on juries. ${ }^{59}$

If the Court is unable to prevent states from changing their peremptory challenge rules, and if it is unwilling to abolish the prosecutor's challenges altogether, the states may be able to destroy the effectiveness of the proposed rule. But the Court should not allow possible evasion to justify avoiding its obligation to ensure representative venires. Moreover, even if legislation on peremptories does become necessary, Congress could not legislate intelligently without first seeing how prosecutors use peremptories when venires fairly represent the Negro population. Thus, at the next opportunity, the Court should require the states to use fair procedures for selecting veniremen.

58. Id. at 341 .

59. There might be speeches and statements affirmatively demonstrating that the solc concern of the law was to enable prosecutors to continue to exclude Negroes from juries. Or the sole concern might be inferred from the fact that there had been no pressurc to change the challenge system for decades-until jury selection procedures werc tightened.

In Gomillion, the discriminatory concern of the state was apparent from the gerrymandering arrangement itself, and no other evidence was needed. But in Davis v. Schnell, 81 F. Supp. 872 (S.D. Ala.), aff'd per curiam, 336 U.S. 933 (1949), a threc-judgc district court used articles and speeches of prominent white citizens to demonstratc that the purpose of a new Alabama voting qualification was to exclude Negrocs. The judges also took note of the fact that the old qualifications had "stood for nearly 50 ycars and [had] provided definite standards for passing upon the qualifications of prospective electors." Id. at 876. See also Brown v. Baskin, 78 F. Supp. 933 (E.D.S.C. 1948), 80 F. Supp. 1017 (E.D.S.C. 1948), aff'd, 174 F.2d 391 (4th Cir. 1949).

It is not certain that the Supreme Court would go as far as these lower courts in finding discriminatory purpose. It should be remembered, however, that the Court has shown a marked willingness to extend its concepts in civil rights cases involving states which attempt to evade the force of its rulings. In particular, note the cxpanding conception of state action in the famous "white primary" cases. Nixon v. Herndon, 278 U.S. 536 (1927); Nixon v. Condon, 286 U.S. 73 (1932); Grovey v. Townsend, 295 U.S. 45 (1985); United States v. Classic, 313 U.S. 299 (1941); Smith v. Allwright, 321 U.S. 649 (1944); Terry v. Adams, 345 U.S. 461 (1953). See Note, 74 Yale L.J. 1448 (1965). 